\title{
Business Process Management in Project-Based Companies: A New Methodology
}

\author{
Sanchez L*, Blanco B \\ Department of Economics, University of Cantabria, Spain. \\ ${ }^{*}$ For Correspondence: E-mail: lidia.sanchez@unican.es
}

\begin{abstract}
Process management is a way of organising and running a business aimed at all kinds of companies that simultaneously pursue an increase in corporate efficiency and an increase in customer satisfaction. The aim is to create added value for the customer by managing the company's processes appropriately. In recent years its importance has increased since it has shown itself to be a tool that improves quality and efficiency in companies. This study presents a new methodology for implementing process management in project production companies, with explicit reference to the particular circumstances of this kind of enterprise. The appropriateness of this study resides in a combination of the current need for process management and the lack of research in this specific field relating to project production companies. The main contribution of this work lies in the clarity and simplicity of the proposed methodology that, in addition, is useful for professionals who want to implement process management in their companies. In turn, that may have a positive impact on society.
\end{abstract}

Keywords: Business process management, Implementation methodology, Modularity, Project-based companies.

\section{Introduction}

Process management is a way of organising and running a business aimed at all kinds of companies that simultaneously pursue an increase in corporate efficiency and an increase in customer satisfaction. The aim is to create added value for the customer by managing the company's processes appropriately. In recent years its importance has increased since it has shown itself to be a tool that improves quality and efficiency in companies, two concepts of vital importance in the current environment, in which only businesses that are competitive both internally and externally survive. Process management therefore has great potential for future expansion and growth. Equally, in the academic sphere there are also many studies, some of them reviewed in this paper, aimed at analysing this issue from multiple perspectives (industries, countries...), thereby corroborating the significance of the subject. However, the review undertaken for this study revealed a niche as regards the introduction of process management in project production companies. Although this organisational system is considered valid for all kinds of organisations, very few studies were found that focus specifically on the application and implementation of the system in project production companies; the research analysed is mainly aimed at continuous production companies. It is known that project production companies have radically different circumstances to continuous production companies, so the implementation, obstacles and advantages of process management are of a different nature, requiring additional analysis. With this in mind, the ultimate aim of this study is to propose a methodology for implementing process management in project production companies.

\section{Process Management}

The origin of process management goes back to the 1980s when, kick-started by Japan, two new management philosophies emerged: Just in Time (JIT) and Total Quality Control (TQC). The two ideologies advocated a production system that is more in touch with customers' needs and the reduction of production defects and waste [1]. These two new approaches refocused business activity, redirecting companies towards customer satisfaction and incorporating the concept of quality as a strategic element for competitiveness that affects the quality of the product, service, delivery, price, management etc. [2].In this context, the traditional functional structures present in the majority of companies, 
characterised by being organised into departments with highly specialised homogenous functions, based on hierarchy, control, formalism and bureaucracy, became insufficient due their lack of flexibility [2].The above can therefore be said to describe the background of process management. However, its proliferation is associated with the arrival of the ISO 9000 International Quality Standards. The close connection between process management and ISO 9001 exemplifies the cause of the incredible rise of the system in recent years. Even so, it is important to bear in mind that the emergence of process management was merely a question of time. Even without the ascendancy of ISO 9001, the current new trends in production systems (Just in Time, Lean Manufacturing, Agile Manufacturing) and the characteristics of the environment would nevertheless, albeit more slowly perhaps, have driven the emergence of this form of management. Process management is a specific way of viewing reality and the company. It perceives the organisation as an interrelated system of processes that combine to help increase customer satisfaction and improve internal efficiency [3]. There are many definitions of what process management consists of and at times there is disagreement among users of the term [4].In this case, the adopted definition is the one provided by ISO 9000 [5], from which the conclusion can be drawn that process management can be defined as the set of mutually related elements within an organisation that enable the policies and objectives associated with its processes to be established, as well as the activities undertaken to achieve these objectives. The greatest achievement of process management is probably its ability to make customer orientation and satisfaction compatible with internal organisational needs (continuous improvement) [2].As for its purpose, the ultimate aim of process management is to focus on the critical aspects to generate value and to ensure customer satisfaction on the one hand and the survival of the company on the other. The objective is therefore to gear the company towards creating value for the client by identifying and managing its processes appropriately [2].The change required within a company to go from a functional and hierarchical structure to a structure based on processes is not easy and the associated risk is high. A mistake when introducing process management can lead to the failure of the system's implementation. The methodologies analysed over the course of the review leading up to this study share, to a greater of lesser extent, the same plan of action (see [617]. All of them start in general terms and narrow down to more specific terms as far as defining processes is concerned, before establishing the measuring mechanisms in each of the processes and, on the basis of this, proposing improvements. In addition, the majority, if not all, of the research on the subject indicates that process management is a system open to any kind of organisation (regardless of its size, industry, country of origin etc). In some cases there is explicit reference to service companies, since they are considered a special case and are completely different to companies that offer tangible products; however, implicitly, much of this research is geared towards continuous or repetitive production and does not so much as mention project production companies which, although included with the production companies, have radically different circumstances. It would be of interest therefore to analyse what project production consists of, what its differences are compared to continuous production and, on this basis, propose a complete methodology for introducing process management systems in project production companies.

\section{Production Systems: Project-based Production}

The study of the various types of production systems is nothing new; to the contrary, as a result of these studies many classifications have been put forward in the literature. This study will adopt the classification proposed by Hill in 1989, one of the most widely used, which distinguishes five types of production system: project, one-off, batch, line and continuous processing. Here is a table of the main features (see Table 1), according to this author, of each of these types. Given that this analysis centres on project production, this type of production system will now be defined in more detail. Project production is typical in the development of services and in making unique and complex products. The size of the products tends to be fairly big, so that, this combined with the specificity of the inputs and outputs, generally means that the inputs are transported to the place where the manufacturing takes place. This kind of organisation is called fixed distribution [18]. Fixed distribution is usually used when, owing to the specifications of the product in question (weight, size, shape, volume), it cannot be transported through the various stages of production. This means that the main product remains immobile, while the rest of the elements, whether they be personnel, machinery or raw materials, are transported to the location of the main product. The exclusivity of this kind of product/service, deriving from its complete adaptation to the client's requirements, means that, every time it is produced, the activities involved can vary. On the basis of these 


\begin{tabular}{|c|c|c|c|c|c|c|}
\hline \multirow{2}{*}{\multicolumn{2}{|c|}{ Aspects }} & \multicolumn{5}{|c|}{ Typical characteristics of process choice } \\
\hline & & Project & $\begin{array}{l}\text { Jobbing, Unit, or } \\
\text { One-Off }\end{array}$ & Batch & Line & $\begin{array}{l}\text { Continuous } \\
\text { processing }\end{array}$ \\
\hline \multicolumn{2}{|c|}{ Type of product } & $\begin{array}{c}\text { Special/small } \\
\text { range of standards }\end{array}$ & Special & $\rightarrow$ & Standard & Standard \\
\hline \multicolumn{2}{|c|}{ Product range } & Wide & Wide & $\rightarrow$ & $\begin{array}{l}\text { Narrow: } \\
\text { standard } \\
\text { product }\end{array}$ & $\begin{array}{l}\text { Very narrow: } \\
\text { standard } \\
\text { products }\end{array}$ \\
\hline \multicolumn{2}{|c|}{ Customer order size } & Small & Small & $\rightarrow$ & Large & Very large \\
\hline \multicolumn{2}{|c|}{$\begin{array}{l}\text { Level of product change } \\
\text { required }\end{array}$} & High & High & $\rightarrow$ & $\begin{array}{l}\text { Low and } \\
\text { within agreed } \\
\text { options }\end{array}$ & None \\
\hline \multirow{2}{*}{\multicolumn{2}{|c|}{$\begin{array}{l}\text { Rate of new product } \\
\text { introductions } \\
\text { What does the company } \\
\text { sell? }\end{array}$}} & High & High & $\rightarrow$ & Low & Very low \\
\hline & & Capability & Capability & $\rightarrow$ & Products & Products \\
\hline \multirow[t]{2}{*}{$\begin{array}{l}\text { How are } \\
\text { orders } \\
\text { won? }\end{array}$} & $\begin{array}{l}\text { Order- } \\
\text { winning } \\
\text { criteria }\end{array}$ & $\begin{array}{c}\text { Delivery } \\
\text { speed/unique } \\
\text { design capability }\end{array}$ & $\begin{array}{c}\text { Delivery } \\
\text { speed/unique } \\
\text { design capability }\end{array}$ & $\rightarrow$ & Price & Price \\
\hline & $\begin{array}{l}\text { Qualifying } \\
\text { criteria }\end{array}$ & $\begin{array}{c}\text { Price/on-time } \\
\text { delivery/conforman } \\
\text { ce quality }\end{array}$ & $\begin{array}{l}\text { Price/on-time } \\
\text { delivery/conform } \\
\text { ance quality }\end{array}$ & $\begin{array}{l}\text { On-time } \\
\text { deilvery/ } \\
\text { conformanc } \\
\text { e quality }\end{array}$ & $\begin{array}{l}\text { Design/On- } \\
\text { time } \\
\text { delivery/confor } \\
\text { mance quality }\end{array}$ & $\begin{array}{l}\text { Design/On-time } \\
\text { delivery/conform } \\
\text { ance quality }\end{array}$ \\
\hline \multicolumn{2}{|c|}{$\begin{array}{l}\text { Nature of the process } \\
\text { technology }\end{array}$} & $\begin{array}{l}\text { Oriented toward } \\
\text { general purpose }\end{array}$ & Universal & $\rightarrow$ & Dedicated & $\begin{array}{l}\text { Highly } \\
\text { dedicated }\end{array}$ \\
\hline \multicolumn{2}{|c|}{ Process flexibility } & High & High & $\rightarrow$ & Low & Inflexible \\
\hline \multicolumn{2}{|c|}{ Production volumes } & Low & Low & $\rightarrow$ & High & Very high \\
\hline \multicolumn{2}{|c|}{ Dominant utilization } & Mixed & Labor & $\rightarrow$ & Plant & Plant \\
\hline \multicolumn{2}{|c|}{ Changes in capacity } & Incremental & Incremental & $\rightarrow$ & $\begin{array}{l}\text { Stepped } \\
\text { change }\end{array}$ & New facility \\
\hline \multicolumn{2}{|c|}{ Key manufacturing task } & $\begin{array}{l}\text { To meet } \\
\text { specification/delive } \\
\text { ry schedules }\end{array}$ & $\begin{array}{c}\text { To meet } \\
\text { specification/deli } \\
\text { very dates }\end{array}$ & $\rightarrow$ & $\begin{array}{l}\text { Low-cost } \\
\text { production }\end{array}$ & $\begin{array}{l}\text { Low-cost } \\
\text { production }\end{array}$ \\
\hline \multicolumn{2}{|c|}{$\begin{array}{l}\text { Level of capital } \\
\text { investment }\end{array}$} & Low/High & Low & $\rightarrow$ & High & Very high \\
\hline \multirow[t]{3}{*}{$\begin{array}{l}\text { Level of } \\
\text { inventory }\end{array}$} & $\begin{array}{l}\text { Component } \\
\text { s/ Raw } \\
\text { material }\end{array}$ & As required & As required/Low & $\begin{array}{l}\text { Often } \\
\text { medium }\end{array}$ & $\begin{array}{l}\text { Planned with } \\
\text { buffer } \\
\text { stocks/low }\end{array}$ & $\begin{array}{l}\text { Planned with } \\
\text { buffer stocks }\end{array}$ \\
\hline & $\begin{array}{l}\text { Work-in- } \\
\text { progress }\end{array}$ & High & High $^{\mathrm{a}}$ & Very high & Low & Low \\
\hline & $\begin{array}{l}\text { Finished } \\
\text { goods }\end{array}$ & Low & Low & $\rightarrow$ & High & High \\
\hline \multirow{3}{*}{$\begin{array}{l}\text { Percentag } \\
\text { e of total } \\
\text { costs }\end{array}$} & Direct labor & Low & High & $\rightarrow$ & Low & Very low \\
\hline & $\begin{array}{c}\text { Direct } \\
\text { materials }\end{array}$ & High & Low & $\rightarrow$ & High & Very high \\
\hline & $\begin{array}{l}\text { Site/plan } \\
\text { overheads }\end{array}$ & Low & Low & $\rightarrow$ & High & High \\
\hline \multirow{2}{*}{$\begin{array}{l}\text { Appropria } \\
\text { te } \\
\text { organizati } \\
\text { onal }\end{array}$} & Control & $\begin{array}{l}\text { Descentralized/cen } \\
\text { tralized }\end{array}$ & Descentralized & $\rightarrow$ & Centralized & Centralized \\
\hline & Style & Entrepreneurial & Entrepreneurial & $\rightarrow$ & Bureaucratic & Bureaucratic \\
\hline \multicolumn{2}{|c|}{$\begin{array}{l}\text { Most important } \\
\text { production management } \\
\text { perspective }\end{array}$} & Technology & Technology & $\rightarrow$ & $\begin{array}{l}\text { Business/Peopl } \\
\text { e }\end{array}$ & Technology \\
\hline \multicolumn{2}{|c|}{$\begin{array}{l}\text { Level of specialist } \\
\text { support to } \\
\text { manufacturing }\end{array}$} & High & Low & $\rightarrow$ & High & Very high \\
\hline
\end{tabular}


characteristics, the next section proposes a methodology for implementing a process management system in a project production company, with a particular focus on the unique features of this kind of company, thereby attempting to provide solutions to the problems that may be caused by these unique circumstances.

\section{Proposed Methodology}

The methodology put forward below is an initial attempt to provide a guide for project production companies interested in implementing a process management system. This methodology is made up of seven stages or steps. At each stage, where applicable the specific characteristics of the project production companies will be indicated, alongside the solutions proposed for these unique features. Each stage is set out below.

\section{Committed Management Team}

The first step required for the implementation of a process management system is the existence of a management team that is interested in and committed to the project. In fact, the process of implementation and improvement progresses in direct proportion to the level of commitment shown by the managers [19].This does not mean that the management will take charge of the project in an exclusive and isolated manner; in reality all the company's staff must be involved, although in many cases it may just be to contribute information and suggestions.

\section{Initial Diagnosis of the Company's Situation}

Once the decision has been made to introduce process management, the first step for the committee to take is to carry out a preliminary diagnosis of the company's situation.It is vital to know the internal situation of the company and the circumstances it faces in order to establish a starting point and, on this basis, set the desired objectives and determine the right measures to meet them.

\section{Planning the Project}

This kind of implementation project can be a burden for the company if it is not properly managed. Thus, establishing the scope of the system is a key factor in its running. A company must establish what areas will be affected by the change, when they will be affected and in what order. Simultaneous implementation of process management in all areas of the company is very risky. Equally, if a company is present in several geographical locations, it can be helpful to implement process management at one location initially in order to detect critical points, problems and obstacles that arise within the company so that modifications can be made to the methodology used and the process is facilitated when it comes to rolling it out to other parts of the organisation. Finally, the company management must establish the budget available to undertake the implementation of process management. It will also be necessary to plan the staff requirements needed to achieve the objective that has been set. As subsequent sections will show, this task is fairly complex because staff requirements arising from implementation must be combined and made compatible with the obligations and regular work of the employees.

\section{Staff Training and Awareness}

Staff participation in the system's implementation process is crucial to its success [20]. Consequently, in order to ensure this participation, the company must make sure employees are motivated and committed to the change, and the way to do this is through training [21].In this regard, project production companies encounter a drawback. As the previous section highlighted, this kind of organisation functions on a made-to-order basis, so that production begins when a customer orders a product. This means that planning is not as precise as it can be in continuous production companies, because there is less control over when production will take place. Instead they must adapt to the times when customers require the product. The immediate consequence of this is that training is especially difficult to schedule around periods of work.

The solution is therefore to establish flexible training schedules. Here are some proposals:

- Holding the same course at different times so that workers can attend at the time that most suits them

- Organising short sessions so that employees do not have to spend the whole day doing the training and can combine it with work

- Establishing agreements with workers so they attend courses outside of their working hours in exchange for time off during quiet periods

- Making use of e-learning

\section{Process Management}

To execute the next step, formation of work teams is recommended. These teams will be made up of the people who participate in each of the processes, since they are the people who know the most about the process in question. They will therefore be multidisciplinary teams that traverse the traditional departments that divide organisations horizontally. $\mathrm{v}$ Identification of company processes. First and foremost, the company's primary processes and the 
relationships between them must be identified. This provides an overview of the company that will be refined over the course of the next stages of the implementation process.

\section{Process Classification}

Processes should be classified according to their purpose; that is, defining whether they are strategic, operational or support processes. This is very useful for companies because, thanks to this classification, a hierarchy between the processes can be established and a schedule can be defined for working with them. It is important to bear in mind that this is just one proposal, because each organisation is responsible for deciding which processes will be implemented first. For instance, a company might decide to start with the processes that involve the largest number of resources or those that are central to achieving the company's objectives.

\section{Analysis of processes}

Once the processes have been identified and prioritised, work centres on each of them separately in order to dig deeper into their content. The analysis begins with the process that has been classed as the most important or priority process. Once this has been done, continuous production companies will generally proceed to identify the sub-processes and sequential relationships between them. However, in project production companies, rather than identifying the sub-processes, the large modules that make up operations must be identified. Modular production, in itself, allows a certain number of basic modules to be manufactured, and these are then used in the assembly of a wide range of different products. Modular production modifies the product design philosophy. Rather than designing each product separately, the aim is to utilise the components by standardising modules that can be used for other products [22].Applying the modular system to process management involves identifying the various standard modules that form each process, so that different modules can be combined for different products, giving rise to a different but standardised process in each case. The modular system is twofold: complementary and alternative. Complementary modules are integrated to the project by addition. The whole project, therefore, is formed from several of these modules, deferring a project of another depending on the modules that comprise it. Thus, the more complex projects have a greater number of modules. For instance, in a shipbuilding project, without being exhaustive, we can find the following modules: "engineering", "hull construction", "piping works", "painting works", etc. According to the specific needs of the ship, the modules outlined above will form part of the project or will not be performed. In turn, within a module, alternative sub-processes may exist. We have to choose the most appropriate one among them for achieving the specific project. For instance, in the engine module, the company should establish as many sub-processes as alternative engines exist and in a specific project choose one of them, just the required. Identifying the modules is considered a more appropriate method due to the main characteristics of project production: the uniqueness of the products. As previously mentioned, although the activities are repeated, each product is something new and, as similar as they may be, they each require a specific set of resources and activities. This is why identifying the common modules that might be combined and applied to different projects appears to be the ideal solution. When the company has identified the modules that make up each process, it can then proceed to break them down into sub-processes, and each module can even contain alternative sub-processes depending on the work to be carried out. Subsequently, each sub-process will be broken down into more simple activities and tasks.

\section{Process Control}

The next step consists of establishing indicators that reveal whether the process is being executed correctly at any given time. Once again, project production companies have added difficulties in this area. Their problems derive from the high level of subcontracting that takes place over the course of their projects. It is common for many tasks in civil engineering works or fixedpositioned manufacturing to be carried out by subcontracted auxiliary companies rather than the company itself. The main reason that justifies this high level of subcontracting is that, via this mechanism, project production companies manage to convert fixed costs into variable costs, making the execution of the project possible. In addition, the large scale of the projects means that, on occasions, it is unviable for a single company to carry out the work within the timeframe established with the client. Consequently, this high level of subcontracting means that the company does not have the same control over the execution of the processes and the modules undertaken by the subcontracted companies responsible for them. Given this situation, the company must attempt to instil the importance of process management beyond its own walls, in this case to the auxiliary companies that work alongside it. Naturally, the ideal situation is one in which the auxiliary companies adopt a process 
management system of their own so that they control themselves. However, since this requirement is often impossible to meet, the company, if it wishes to increase its level of control over subcontracted work, will have to require the auxiliary companies to measure the indicators that it deems necessary in order to ensure that the work is being carried out as planned. Another possible solution which is used by some companies is to form mixed teams of its own personnel and subcontracted staff, so that the company's own workers, trained and committed to the company's management, control and measure the work carried out by the team.

\section{Improvement of Processes}

Improving processes and, in general, the work carried out in the company, should not be an exceptional occurrence, but should become everyday practice within the company. A lack of improvement causes the organisation to stagnate and, in many cases, leads to a loss of competitiveness. This is why it is important to determine the indicators and, having compared them with the objectives set, if deviations have been detected, those responsible for each process should define potential areas for improvement. Once the deviations have been detected and the lines of action established, the processes can be improved in two different ways: via continuous improvement or through process reengineering. Once the improvements have been applied and in the event that the objectives set have been met, the company will have to set new standards which, on the one hand will enable the consolidation of the improvements carried out to date, and on the other hand will pose a new challenge for the company, which will have to start a new process of improvement (checkmeasure-improve).

\section{Conclusions}

The main contribution of this study consists of its proposal of a new implementation methodology for process management in project production companies. To achieve this, firstly the importance of process management was analysed and highlighted as a practice that is becoming

\section{References}

1. Flynn BB, Sakakibara S, Schroeder RG (1995) Relationship between JIT and TQM: practices and performance.The Academy of Management Journal, 38(5):1325.1360.

2. Pérez Fernández de Velasco JA (2004) Gestión por procesos: cómo utilizar ISO 9001:2000 para mejorar la gestión de la organización. ESIC, Madrid.

3. Benner MJ, Tushman ML (2003) Exploitation, increasingly prevalent in business worldwide. Its success is a result of its ability to combine internal efficiency needs with customerorientation, two key factors for the competitiveness and survival of a company, whatever its type. The literature review carried out revealed that there were very few studies that linked process management to project production companies. In view of this discovery it was decided that a specific analysis of the characteristics of project production companies would be of value. The conclusion that can be drawn is that the main characteristics of these companies are: unique and heterogeneous products, a high level of subcontracting, made-toorder production, a high level of client participation, a high level of productive flexibility and fixed-plant type distribution. On the basis of these characteristics a methodology is proposed that comprises seven stages: commitment of the management team, initial diagnosis of the company's situation, project planning, staff training and awareness, process management, process control and process improvement.

The newest points of the proposed methodology are:

- The use of modularity

- The modular system is doubly useful. First, it allows us to establish complementary modules that may or may not be added to the achievement of a specific project; and secondly, it offers the possibility of creating alternative modules that will be selected depending on the specific needs of each project.

- Proposals to combine work schedules with training times: this is not an easy task due to the instability of demand in project based companies.

- Proposals to ensure an effective control of processes: this is a difficult point to achieve in these businesses because of the high degree of existing outsourcing.

It is, therefore, a different and novel methodology with respect to those revised in the literature. It highlights the modular approach and tries to extend process management to the other links in the subcontracting chain.

Exploration, and Process Management: The productivity dilemma revisited. The Academy of Management Review. 28(2):238-56.

4. Ravesteyn P, Batenburg R (2010) Surveying the critical success factors of BPM-systems implementation, Business Process Management Journal 16(3): 492-506.

5. International Organization for Standardization 
(ISO) (2008) Norma Internacional ISO 9001:2008. $4^{\mathrm{a}}$ edn. Secretaría Central de ISO, Suiza.

6. Armistead C, Pritchard JP (1999) Business process management - lessons from European business. Business Process Management Journal. 5(1):10.

7. Carmignani G (2008) Process-based management: A structured approach to provide the best answers to the ISO 9001 requirements. Business Process Management Journal. 14(6):803-12.

8. Corallo A, Margherita A, Scalvenzi M, Storelli D (2010) Building a process-based organization: The design roadmap at superjet international. Knowledge and Process Management. 17(2): 49-61.

9. DeToro I, McCabe T, (1997) How to stay flexible and elude fads. Quality Progress. 30(3):55.

10.Elzinga DJ, Horak T, Chung-Yee L, Bruner C (1995) Business process management: survey and methodology. Engineering Management, IEEE Transactions. 42(2):119-28.

11.Kohlbacher M (2010) The effects of process orientation: a literature review. Business Process Management Journal. 16(1):135.

12.Melan EH (1989) Process Management: A unifying framework for improvement. National Productivity Review. 8(4):395.

13. Paper D (1998) BPR: creating the conditions for success. Long Range Planning. 31(3): 426-435.

14. Paper D, Rodger JA, Pendharkar PC (2001) A BPR case study at Honeywell. Business Process
Management Journal. 7(2):85-99.

15.Sedín Caballero J (2004) Diseño en implantación de un sistema de gestión por procesos: Los procesos deben ser definibles, predecibles, repetitivos y entendidos por el personal correspondiente. Qualitas hodie: Excelencia, desarrollo sostenible e innovación. 96:6-10.

16. Sentanin OF, Almada Santos FC, Chiappetta Jabbour CJ (2008) Business process management in a Brazilian public research centre. Business Process Management Journal 14(4): 483-496.

17.Weinrach J (2006) Process and processase. Environmental Quality Management 15(3):81-85.

18.Domínguez Machuca JA et al. (1995) Dirección de Operaciones. Aspectos estratégicos en la producción y los servicios. McGraw Hill/Interamericana de España, S.A., Madrid.

19.Harrington HJ (1988) Cómo incrementar la calidad - productividad en su empresa. McGraw Hill, México.

20.Reger RK, Gustafson LT, Demarie SM, Mullane JV (1994) Reframing the Organization: Why Implementing Total Quality is Easier Said Than Done. The Academy of Management Review 19(3):565-584.

21.Klein KJ, Sorra JS (1996) The challenge of innovation implementation. The Academy of Management Review. 21(4):1055-80.

22.Fernández Sánchez E (1993) Dirección de la Producción. Fundamentos Estratégicos. Civitas, Madrid. 